\title{
Economic Fundamentals Over Long and Short Horizons
}

Ali TFAILY $Y^{1}$

\begin{abstract}
In this paper, the idea that economic fundamentals should hold over all horizons is put to the test by focusing on the dynamics of the foreign exchange market. An empirical proof that the foreign exchange market follows economic fundamentals over long horizons but not over short horizons is presented. This can be generalized to other markets such as stocks or commodities, which are mostly driven by speculations and investors' expectations over short horizons but follow economic fundamentals over long horizons. This is especially true for highly volatile assets where the high volatility masks the economic fundamentals over the short run.
\end{abstract}

Keywords: Foreign Exchange Market, Exchange Rate, Uncovered Interest Rate Parity, Covered Interest Rate Parity, Economic Fundamentals.

JEL classification: F12, F17, F31

DOI: $10.24818 /$ RMCI.2018.2.167

\section{Introduction}

The foreign exchange market (FX-market) is the most active of all financial markets. The daily volume of foreign exchange transactions was U.S. Dollar 5.1 trillion on average in April of 2016, where $88 \%$ of the transactions exchange currencies for U.S. Dollar (Bank of International Settlements Papers, 2016). To get a sense of how big the number is, consider that the world yearly GDP in 2016 was U.S. Dollar 75.64 trillion (World Bank, 2017) which makes an average of U.S. Dollar 207.23 billion as a daily world GDP for this year. The fact that the FX-market is much higher than real goods and services trading has attracted researchers to study this market in details. In this paper, an empirical proof that the FX-market follows economic fundamentals over long horizons but not over short horizons is presented. The rest of the paper is structured as follows: a literature review section discussing the most well know theory explaining the dynamics of the FX-market is presented followed by a methodology section and a case study section covering the case of the U.S. Dollar and British Pound exchange rate (EUSD/GBP); results, discussions and conclusions are then presented.

\footnotetext{
${ }^{1}$ Ali Tfaily, Bucharest University of Economic Studies, Bucharest, Romania, E-mail: tfaily.ali@gmail.com
} 


\section{Literature Review}

The most well know theory explaining the dynamics of the FX-market is the Interest Rate Parity. It is a no-arbitrage condition representing an equilibrium state under which investors will be indifferent between the interest rates available in two countries. Three assumptions are central to interest rate parity: free movement of capital, negligible transaction costs and perfect substitutability of domestic and foreign assets (mainly in terms of risk, maturity, liquidity and tax treatment). Interest Rate Parity takes on two distinctive forms: Uncovered Interest Rate Parity (UIP) and Covered Interest Rate Parity (CIP). More precisely, the UIP equates the rate of return on domestic currency with the expected rate of return on foreign currency.

The UIP equation is: $R=R^{*}+\frac{E^{e}-E}{E}$

In which, the exogenous variables are:

$1 \quad R$ : Domestic nominal interest rate

$2 R^{*}$ : Foreign nominal interest rate

$3 E^{e}$ : Expected future exchange rate

And the only endogenous variable is the spot exchange rate $E$. That is, UIP is an exchange rate determination theory.

The CIP equation is: $R=R^{*}+\frac{F-E}{E}$

In which the exogenous variables in the CIP equation are:
$4 \quad R$ : Domestic nominal interest rate
$5 \quad R^{*}$ : Foreign nominal interest rate
$6 \quad E$ : Spot exchange rate

And the only endogenous variable is $F$, the forward exchange rate. That is, CIP is a forward exchange rate determination theory.

The intuition behind the CIP is that if $R=R^{*}+\frac{F-E}{E}$ did not hold, profitable market arbitrage opportunity could be done without any risk (i.e. if $R$ is lower than 
$R^{*}+\frac{F-E}{E}$ one could make riskless profit by investing in foreign assets and in a forward contract).

Minimal empirical evidence exists in support of UIP, though evidence is stronger in favor of CIP. Most observers agree that the market respects the CIP no arbitrage condition, as banks allow forward exchange rates to be set by interest differentials (Kenneth et al., 1990). Chinn (2007) discusses that CIP holds if capital moves freely (for developed economies CIP holds fairly well; prior to the dismantling of capital controls and in many emerging markets today CIP is unlikely to hold). Frenkel and Levich (1975) claim the CIP is valid in the short-run if transaction costs are included in the model. Taylor (1989) found that CIP holds during relatively calm periods in the foreign exchange and the money markets, although did not hold during periods of market turbulence.

\section{Methodology}

In this section, a detailed description of how to test UIP is presented. The equation of UIP is, as noted in the previous section: $R=R^{*}+\frac{E^{e}-E}{E}$

The assumptions behind UIP are (as noted previously):

- Free movement of capital

- Negligible transaction costs

- Perfect substitutability of domestic and foreign assets (mainly in terms of risk, maturity, liquidity and tax treatment)

Because of the increase in economic interdependence of nations across the world (especially for developed economies) one could justify the first two assumptions.

To empirically test the UIP equation, we must run the following equation:

$$
\begin{aligned}
& R=R^{*}+\frac{E^{e}-E}{E} \\
& \Rightarrow \quad R-R^{*}=\frac{E^{e}-E}{E} \\
& \Rightarrow \quad R-R^{*} \approx \ln \left(E^{e}\right)-\ln (E)
\end{aligned}
$$

This will make the UIP regression equation: $\ln \left(E^{e}{ }_{t}\right)-\ln \left(E_{t}\right)=\alpha_{1}+\alpha_{2} \times\left(R_{t}-R^{*}{ }_{t}\right)+u_{t}$ where $u_{t}$ is an error term. 
Because expectations are not observable, one must assume that expectations are rational, that is: $\ln \left(E^{e}{ }_{t}\right)=\ln \left(E_{t+1}\right)+\rho_{t}$ where $\rho_{t}$ is an error term uncorrelated with any information present at time $t$. This will make the regression equation to run:

$\ln \left(E_{t+1}\right)-\ln \left(E_{t}\right)=\alpha_{1}+\alpha_{2} \times\left(R_{t}-R_{t}^{*}\right)+u_{t}$, where $u_{t}$ is a new error term.

One aspect that gives strength and popularity to the UIP equation is that it can be applied over short and long horizons.

What we have in the literature is the following:

a. Over short horizons: (less than one year)

The UIP lack of ability to explain exchange rate movements, when tested under rational expectations, is most probably caused by expectation error (i.e. rejection of rational expectations and development of models that affect the dynamic of exchange rate expectations).

Experimental and survey data studies (Taylor and Allen (1992), Bloomfield and Hales (2002), Frankel and Froot (1987)) reject evidence of rational expectations and found evidence of adaptive, regressive, bandwagon (trend following expectations mechanism) and distributed lag expectations.

To explain the behavior of exchange rate over short horizons, economists are developing models that are based on investors' expectations. Some of these models are:

- Exchange rate overshooting hypothesis, it is a theoretical explanation of high exchange rate volatility based on investors' expectations.

- A simple model introduced by Gourinchas and Tornell (2004), they assume that investors think that shocks to the interest rate differential are more temporary than they actually are.

- Illut (2009) introduced ambiguity aversion in a context where investors have imperfect knowledge about the underlying model. The author considered a model where investors do not know the true variance of temporary shocks to the interest rate differential.

- Burnside et al. (2011) introduced overconfident investors in the sense that they underestimate the variance of signals about future monetary policy.

Also, it is well known that over short horizons the exchange rates are more volatile than economic fundamentals (Burnside et al. 2011). 
b. Over long horizons:

A small amount of studies have tested UIP over longer horizons (i.e. using long horizon changes in the exchange rate and interest rates on long term bonds). Some of these studies:

- Flood and Taylor (1997) used medium term government bonds (3 years), the data were pooled for a sample of 21 countries, and they documented evidence for UIP at long horizon.

- Alexius (2001) examined 14 long term government bonds of different maturities for the 1957 till 1997 period. Her study also found evidence of UIP at long horizon but it is difficult to interpret the significance of the results since her data contained periods of fixed exchange rates and fixed capital control.

- Chinn et al. (2004) found that at longer horizons (3, 5, 10 years) the evidence is stronger in favor of UIP and the rational expectations hypothesis.

In the next section, I will test the idea that the FX-market is mostly driven by investors' expectations over short horizons but follows economic fundamentals over longer horizons by running UIP assuming rational expectations over short and long horizons.

\section{Case Study}

In this empirical study, the domestic currency is the U.S. Dollar (USD) and the foreign currency is the British Pound (GBP). Interest rates on government bonds of the same maturity will be used; these bonds can be assumed to be perfect substitutes in terms of risk and liquidity.

UIP is tested using data from 1993 till 2007. Data after 2007 were not used since the post 2007 period was full of financial crises and financial markets could have unusual behavior during a financial crisis (the 2008 subprime financial crisis, the Eurozone debt crisis that started at the end of 2009 and the Brexit or the withdrawal of the United Kingdom from the European Union that took place on June 2016).

The regression equation of UIP assuming rational expectations is (as noted previously):

$$
\begin{aligned}
& \ln \left(E_{t+1}\right)-\ln \left(E_{t}\right)=\alpha_{1}+\alpha_{2} \times\left(R_{t}-R^{*}{ }_{t}\right)+u_{t} \\
& \Rightarrow \Delta E_{t}=\alpha_{1}+\alpha_{2} \times\left(R_{t}-R_{t}^{*}\right)+u_{t}
\end{aligned}
$$

And now with,

- $R$ : Nominal interest rate on USD government bonds

- $R^{*}$ : Nominal interest rate on GBP government bonds

- $E: \mathrm{E}_{\mathrm{USD} / \mathrm{GBP}}$ 
Also,

- $\Delta E_{t}$ : Represent the change in the exchange rate EUSD/GBP over the period covered by the interest differential. Exchange rate data are end of quarter exchange rates downloaded from the Bank England website.

- $R_{t}-R^{*}{ }_{t}$ : The maturity of the government bonds is the same as the period covered by $\Delta E_{t}$. The interest rates on government bonds are end of quarter interest rates downloaded from the Bank of England website and from the Federal Reserve website.

If UIP holds, one must get $\alpha_{2}$ not significantly different than one.

a. Over short horizons: (less than one year)

In this section, UIP is tested using interest rates on three, six and twelve month government bonds.

Table 1: Three moth horizon test of UIP

\begin{tabular}{|c|c|c|c|c|c|}
\hline \multicolumn{6}{|c|}{$\Delta E_{t}=\alpha_{1}+\alpha_{2} \times\left(R_{t}-R^{*}\right)+u_{t}$} \\
\hline Time & $\alpha_{1}$ & $\alpha_{2}$ & $\mathrm{R}^{2}$ & Residuals & $\mathrm{N}$ \\
Period & & & & Normality Test & \\
\hline 1993q1- & -0.000704 & -1.757236 & 0.0209 & Jarque-Bera $=$ & 46 \\
$2007 \mathrm{q} 3$ & $(0.009692)^{*}$ & $(1.99083)$ & & 1.547 & \\
& $0.94 * *$ & 0.38 & & p-value $=0.461$ & \\
& & & & & \\
\hline
\end{tabular}

* HAC standard errors (Newey-West).

$* *$ p-value for $\mathrm{H}_{0}$ : estimator $=0$.

Table 2: Six moth horizon test of UIP

\begin{tabular}{|c|c|c|c|c|c|}
\hline \multicolumn{6}{|c|}{$\Delta E_{t}=\alpha_{1}+\alpha_{2} \times\left(R_{t}-R^{*}\right)+u_{t}$} \\
\hline Time & $\alpha_{1}$ & $\alpha_{2}$ & $\mathrm{R}^{2}$ & $\begin{array}{c}\text { Residuals } \\
\text { Normality Test }\end{array}$ & $\mathrm{N}$ \\
Period & & & & Jarque-Bera $=$ & 55 \\
\hline 1993q1- & 0.0029 & -1.301 & 0.021 & 1.429 & \\
$2007 \mathrm{q} 2$ & $(0.0144)^{*}$ & $(1.697)$ & & p-value $=0.48$ & \\
& $0.83 * *$ & 0.44 & & & \\
& & & & & \\
\hline
\end{tabular}

* HAC standard errors (Newey-West).

$* * \mathrm{p}$-value for $\mathrm{H}_{0}$ : estimator $=0$.

172 Review of International Comparative Management

Volume 19, Issue 2, May 2018 
Table 3: Twelve moth horizon test of UIP

\begin{tabular}{|c|c|c|c|c|c|}
\hline \multicolumn{6}{|c|}{$\Delta E_{t}=\alpha_{1}+\alpha_{2} \times\left(R_{t}-R^{*}\right)+u_{t}$} \\
\hline Time & $\alpha_{1}$ & $\alpha_{2}$ & $\mathrm{R}^{2}$ & $\begin{array}{c}\text { Residuals } \\
\text { Normality Test }\end{array}$ & $\mathrm{N}$ \\
Period & & & & 56 \\
\hline 1993q1- & 0.0069 & -1.273 & 0.034 & Jarque-Bera & 56 \\
$2006 \mathrm{q} 4$ & $(1.554)^{*}$ & $(1.554)$ & & 1.067 & \\
& $0.77 * *$ & 0.416 & & p-value $=0.58$ & \\
& & & & & \\
\hline
\end{tabular}

* HAC standard errors (Newey-West).

$* *$ p-value for $\mathrm{H}_{0}$ : estimator $=0$.

From the above three tables, UIP does not hold over short horizons $\left(\alpha_{2}\right.$ is not significantly different than zero). Also, the $\mathrm{R}^{2}$ is extremely low.

b. Over long horizons:

In this section, I will run UIP using interest rates on seven years government bonds.

Table 4: Seven years horizon test of UIP

\begin{tabular}{|c|c|c|c|c|c|c|}
\hline \multicolumn{7}{|c|}{$\Delta E_{t}=\alpha_{1}+\alpha_{2} \times\left(R_{t}-R_{t}^{*}\right)+u_{t}$} \\
\hline $\begin{array}{l}\text { Time } \\
\text { Period }\end{array}$ & $\alpha_{1}$ & $\alpha_{2}$ & $\mathrm{R}^{2}$ & $\mathrm{H}_{0}: \alpha_{2}=1$ & $\begin{array}{c}\text { Residuals } \\
\text { Normality } \\
\text { Test }\end{array}$ & $\mathrm{N}$ \\
\hline $\begin{array}{l}\text { 1993q1- } \\
2000 \mathrm{q} 4\end{array}$ & $\begin{array}{c}0.125 \\
(0.026)^{*} \\
0.00^{* *}\end{array}$ & $\begin{array}{c}0.832 \\
(0.1945) \\
0.00\end{array}$ & 0.585 & $\begin{array}{c}\text { t-stat }=- \\
0.858 \\
\text { p-value }= \\
0.397\end{array}$ & $\begin{array}{c}\text { Jarque-Bera }= \\
0.168 \\
\text { p-value }= \\
0.91\end{array}$ & 32 \\
\hline
\end{tabular}

* HAC standard errors (Newey-West).

$* *$ p-value for $\mathrm{H}_{0}$ : estimator $=0$.

From the above table, over seven years horizon, UIP holds $\left(\alpha_{2}\right.$ is not significantly different than one). Also, the ability of UIP to explain exchange rate changes had significantly increased (the $\mathrm{R}^{2}$ had significantly increased).

To sum up, the empirical results are consistent with the literature, the FX-market is mostly driven by investors' expectations over short horizons but it follows economic fundamentals over long horizons. 


\section{Conclusions}

In this paper, an empirical proof that the FX-market follows economic fundamentals over long horizons and not over short horizons was presented. This can be generalized to other markets (stocks, commodities...), which are mostly driven by speculations and investors' expectations over short horizons but follow economic fundamentals over long horizons (this is especially true for highly volatile assets where the high volatility masks the economic fundamentals over the short run).

\section{References}

1. Alexius, A. (2001), "Uncovered Interest Parity Revisited", Review of International Economics 9, 505-517.

2. Bank of International Settlements Papers (2016), "Foreign exchange turnover in April 2016".

3. Bloomfield, R. and Hales, J. (2002), "Predicting the Next Step of a Random Walk: Experimental Evidence of Regime-Shifting Beliefs", Journal of Financial Economics, 65 (3): 397-414.

4. Burnside, C., Eichenbaum, M. and Rebelo, S. (2011),"Carry Trade and Momentum in Currency Markets", National Bureau of Economic Research.

5. Chinn, M. (2007), "Interest Rate Parity", Princeton Encyclopedia of the World Economy.

6. Chinn, M. and Meredith, G. (2004), "Monetary Policy and Long-Horizon Uncovered Interest Parity", IMF Staff Papers Vol. 51, No. 3.

7. Flood, R.P. and Taylor, M.P. (1997), "Exchange Rate Economics: What's Wrong with the Conventional Macro Approach?", Chicago: Univ. of Chicago Press for NBER, pp. 262-301.

8. Frankel, J.A. and Froot, K.A. (1987), "Using Survey Data to Test Standard Propositions Regarding Exchange Rate Expectations", American Economic Review Vol. 77, No. 1, pp. 133-153.

9. Frenkel, J.A. and Levich, R.M. (1975), "Covered Interest Arbitrage: Unexploited Profits", Journal of Political Economy, 83, 325-338.

10. Froot, K.A. and Thaler, R.H. (1990), "Anomalies: Foreign Exchange", The Journal of Economic Perspectives, Vol. 4, No. 3, pp. 179-192.

11. Gourinchas, P. and Tornell, A. (2004), "Exchange Rate Puzzles and Distorted Belief", Journal of International Economics, Elsevier, vol. 64(2).

12. Krugman, P., Obstfeld, M. and Melitz, M. (2012), "International Economics: Theory and Policy", 9th Edition, Pearson.

13. Taylor, M.P. (1989), "Covered Interest Arbitrage and Market Turbulence", Economic Journal, Vol. 99, pp. 376-91.

14. Taylor, M. P. and Allen, H. (1992), "The Use of Technical Analysis in the Foreign Exchange Market", Journal of International Money and Finance, 11(3), 304-314.

15. World Bank (2017), "World Development Indicators Database".

174 Review of International Comparative Management

Volume 19, Issue 2, May 2018 